\title{
Analysis of the relationship between body posture and postural stability in girls aged $10-12$ years
}

\section{Analiza związków pomiędzy postawą ciała a stabilnością posturalną u dziewcząt w wieku 10-12 lat}

\author{
Katarzyna Bieniek ${ }^{1}$, Jacek Wilczyński² \\ Jan Kochanowski University Graduate in Physiotherapy, Faculty of Health Sciences, Jan Kochanowski University, Kielce, Poland \\ Head of the Faculty: Prof. Marianna Janion MD, PhD \\ ${ }^{2}$ Posturology Department, Hearing and Balance Rehabilitation, Faculty of Medicine and Health Sciences, Jan Kochanowski University, \\ Kielce, Poland \\ Head of the Department: Prof. JKU Jacek Wilczyński MD, PhD
}

Key words: central stabilisation, Diers Formetric III 4D method, Biodex Balance System.

Słowa kluczowe: stabilizacja centralna, metoda Diers Formetric III 4D, Biodex Balance System.

\begin{abstract}
Introduction: Studies assessing the influence of postural stability on body posture are very important in postural diagnosis and re-education.

Aim of the research: To analyse the relationship between body posture and postural stability.

Material and methods: The research included 146 girls aged 10-12 years from three Kielce primary schools. The Diers Formetric III 4D optoelectronic method was used to assess body posture. Postural stability was tested using the Biodex Balance System platform.

Results: Spearman's rank correlation coefficient showed a directly proportional relationship between body posture parameters and kyphotic apex, lumbosacral point of inflection, the maximal lordosis angle and the angle of lordosis measured between tangibles of the surface of the lumbosacral point and medial point between lordotic dimples. On the side of parameters showing inversely proportional correlations, the following were found: trunk lenght measured from vertebra C7 to the medial point between lordotic dimples, trunk lenght measured from vertebra C7 to the beginning of the gluteal cleft and trunk inclination expressed in millimeters and degrees.
\end{abstract}

\section{Streszczenie}

Wprowadzenie: Badania oceniające wpływ stabilności posturalnej na postawę ciała są bardzo istotne w diagnostyce oraz reedukacji posturalnej.

Cel pracy: Analiza związków pomiędzy postawą ciała a stabilnością posturalną.

Materiał i metody: Badaniami objęto 146 dziewcząt w wieku 10-12 lat z trzech kieleckich szkół podstawowych. Do oceny postawy ciała zastosowano metodę optoelektroniczną Diers Formetric III 4D. Stabilność posturalną testowano przy użyciu platformy balansowej - Biodex Balance System.

Wyniki: Korelacja rang Spearmana wykazała wprost proporcjonalną zależność pomiędzy parametrami postawy ciała a szczytem kifozy, punktem przegięcia lędźwiowo-krzyżowego, maksymalnym kątem lordozy oraz kątem lordozy zmierzonym między stycznymi do powierzchni lędźwiowo-krzyżowego punktu przegięcia. Do parametrów, które wykazywały korelacje odwrotnie proporcjonalne, należały: długość tułowia zmierzona od kręgu C7 do punktu środkowego między dołkami lędźwiowymi, długość tułowia od kręgu C7 do początku szpary pośladkowej oraz nachylenie tułowia wyrażone w stopniach i milimetrach.

\section{Introduction}

Proper and stable posture is an indicator of biomechanical efficiency, muscle balance, and neuromuscular coordination [1]. It develops on the correct morphological and functional basis. This means that the following are necessary: proper structure of the bone-joint sys- tem, the correct length and flexibility of soft periarticular components (fascia, bags, ligaments), and above all, correct functioning of antigravity muscles. According to the concept of neurodevelopment, body posture is considered as the effect of central regulation system efficiency, which is dependent on the antigravity system. 
It develops gradually in the first year of life and consists of proper: postural tension, postural and motor patterns, sensory information, and reciprocal innervation $[2,3]$. It provides the ability to actively oppose the power of gravity, allowing one to perform all movements, including efficient movement in a manner characteristic for a given stage of motor development $[4,5]$. A characteristic feature of posture is vertical positioning of the body axis in relation to a small support plane. Such orientation in the gravitational field causes a person to be constantly exposed to loss of balance. Therefore, it is necessary to constantly perform corrective movements, restoring the proper position of the centre of gravity relative to the support plane. The morphological base of regulation is the organ of movement; the controlling function is performed by the nervous system [6]. Postural stability is the ability of joints to restore and maintain proper balance by compensating for the forces acting on the body. It is related to dynamic capabilities and properties as well as characteristics of all the systems involved in maintaining balance [7]. Stability assessment is enabled by analysis of the signal representing the application point of the centre of pressure (COP) resultant force. This signal is a superposition of centre of gravity (COG) with corrective effects of the movement apparatus, aimed at providing a stable standing position [8]. The focal mechanisms maintaining balance are anticipation adjustments and corrective postures that have a significant impact on the adoption of correct posture.

\section{Aim of the research}

The aim of the study was to answer the question of what relationship exists between the posture of the body and postural stability in girls aged 10-12 years.

\section{Material and methods}

The research covered a group of 142 girls aged 10-112 years from the Świętokrzyskie Province. The most numerous group included 10 -year-old girls, comprised of 65 (45.77\%) participants, then the 11-year-olds - 47 (33.1\%) individuals, and the least numerous group included 12-year-old girls - 30 (21.13\%) persons.

The average height of the examined girls at the age of 10 years was $143.44 \mathrm{~cm}$, the average body weight reached $36.33 \mathrm{~kg}$, while the average body mass index (BMI) was $17.62 \mathrm{~kg} / \mathrm{m}^{2}$. In the group of 11-year-old girls, the average body height was $150.7 \mathrm{~cm}$, the average body weight of the subjects was $40.18 \mathrm{~kg}$, and the BMI reached the average value of 17.53. Among girls aged 12 years, the mean body height was $160.2 \mathrm{~cm}$, the average body weight was $47.66 \mathrm{~kg}$, while the BMI index reached the average value of 18.48 .

The selection of subjects was done randomly, in accordance with the principle of randomisation, after prior determination of the criteria to be complied with by each group. Prior to the research, its purpose, course, and duration were determined. Then, the child's par- ents gave written consent for participation in the study. All research procedures were carried out in accordance with the 1964 Declaration of Helsinki and with consent of the University Bioethics Committee for Research at Jan Kochanowski University in Kielce (Resolution No. 5/2015).

\section{Body posture examination}

Body posture was assessed using the Diers Formetric III $4 \mathrm{D}$ optoelectronic method. The method allows photogrammetric video registration of the back surface using a raster stereography process [9-11]. Based on the obtained data, a precise three-dimensional model of the back surface was created [12]. The essence of the device is analysis of the back form. Taking anatomical and biomechanical assumptions of the model into account, it was possible to calculate permanent anatomic points, spine curvatures and parameters of spatial trunk forms $[13,14]$. The following parameters were used to describe the body posture of the examined girls:

- trunk length VP-DM (mm), the length measured from vertebra $\mathrm{C} 7$ to the medial point between lordotic dimples,

- trunk length VP-SP (mm), the length measured from vertebra $\mathrm{C} 7$ to the beginning of the gluteal cleft,

- trunk inclination VP-DM (mm), the difference in height between VP (vertebra C7) and DM (medial point between lordotic dimples DL-DR) relative to the vertical plane, with a positive value of the variable, VP is more in front than DM,

- trunk inclination VP-DM $\left({ }^{\circ}\right)$, the difference in height between VP (vertebra C7) and DM (medial point between lordotic dimples DL-DR) relative to the vertical plane, with a positive angle value, VP is more in front than DM,

- inflection point ICT ( $\mathrm{mm})$, is the cervico-thoracic point of inflection, i.e. the point of highest inclination of the surface within the cervical segment (above the kyphosis peak),

- kyphotic apex (VPDM) (mm), is the rear end of the sagittal profile within the thoracic segment of the spine,

- inflection point ITL (mm), it is the thoracic-lumbar inflection point, i.e. the point of highest negative inclination of the surface in the area between the kyphosis peak and lordosis peak,

- lordotic apex LA (VPDM) (mm), is the frontal peak of the sagittal profile in the lumbar area of the spine,

- inflection point ILS ( $\mathrm{mm}$ ), is the lumbosacral point of inflection, thus the highest positive inflection point between the peak of lordosis and sacral kyphosis,

- kyphotic angle ICT-ITL $(\max )\left(^{\circ}\right)$, is the maximal angle of kyphosis measured between the tangible of the surface of the ICT upper inflection point near VP and the ITL lumbosacral inflection point,

- kyphotic angle VP-ITL $\left(^{\circ}\right)$, is the kyphosis angle between VP and the lumbosacral point of ITL inflection, 
- lordotic angle ITL-ITS (max) $\left(^{\circ}\right)$, is the maximal lordosis angle measured between tangibles of the lumbosacral area inflection point of ITL and the lower lumbosacral ILS inflection point,

- lordotic angle ITL-DM $\left(^{\circ}\right)$, is the angle of lordosis measured between tangibles of the surface of the lumbosacral point of ITL and DM inflection [15].

\section{Postural stability testing}

Analysis of postural stability was carried out using the Biodex Balance System balance platform. The device assessed the ability to maintain posture on a stable surface. The analysed parameters were:

- Overall total stability index (SI), reflecting variability of the platform's position from the horizontal plane, expressed in degrees, during all movements performed in the test. A high value indicates a large number of movements performed during the test.

- Anterior/posterior stability index (A/P), reflecting variability of the platform position for movements in the sagittal plane, expressed in degrees.

- Medial/lateral stability index (M/L), reflecting variability of the platform position for movements in the frontal plane, expressed in degrees [16].

Body posture examination was carried out with the DiCAM programme using the average measurement, consisting of a sequence of 12 pictures that, by creating an average value, reduce postural variance and thereby improved the clinical value of the study [17]. During measurements, the patient was undressed to shorts that exposed part of the buttocks. The girls who had long hair put it up so that the cervical part of the spine could be seen.

During postural stability analysis, the Postural Stability Test was performed with both feet on a stable surface and with open eyes. The test consisted of three samples. The duration of the test was $20 \mathrm{~s}$, separated by 10 -second intervals. The patient's eyesight during the examination was focused on the monitor screen, where a characteristic dot appeared (COP) - Centre of Pressure, the symbolic representation of the Centre of Mass (COM). The subject's task was to balance the body so that the dot (COP) remained in the middle of the circle visible on the monitor at the point of intersection of the coordinate axes [18]. Patient scoring in the postural stability test depended on the number and size of COP deviations per unit of time. This means that the lower the result, the better the postural stability.

\section{Statistical analysis}

The independent variables were parameters of postural stability, while the dependent ones were body posture parameters. People with postural disorders generally show higher values of all the abovementioned parameters. Variables were verified in terms of normality using the Shapiro-Wilk test. The interdependence of scale type features was investigated using Spearman's correlation test. Statistical significance was assumed at the level of $p<0.05$.

\section{Results}

Along with the increase in the overall stability index, there was an increase in the value of kyphosis peak KA (VPDM) $(R=0.22 ; p=0.007)$, inflection point ILS $(R=0.2 ; p=0.016)$, and lordosis angle ITS$\mathrm{DM}(R=0.25 ; p=0.003)$. Inversely proportional correlations were found between the overall stability index and trunk length VP-DM $(R=-0.21 ; p=0.012)$, trunk length VP-SP $(R=-0.12 ; p=0.017)$, trunk inclination VP-DM $(R=-0.22 ; p=0.008)$, and trunk inclination

Table 1. Correlations between overall stability index and body posture parameters in the group of studied girls

\begin{tabular}{|c|c|c|c|c|}
\hline Correlated parameters & $N$ & Spearman $R$ & $t(N-2)$ & $P$-value \\
\hline Overall stability index $\left[^{\circ}\right] /$ trunk length VP-DM [mm] & 142 & -0.21 & -2.537 & 0.012 \\
\hline Overall stability index $\left[^{\circ}\right] /$ trunk length VP-SP [mm] & 142 & -0.12 & -2.408 & 0.017 \\
\hline Overall stability index $\left[^{\circ}\right] /$ trunk inclination VP-DM $\left[^{\circ}\right]$ & 142 & -0.22 & -2.704 & 0.008 \\
\hline Overall stability index $\left[^{\circ}\right] /$ trunk inclination VP-DM [mm] & 142 & -0.24 & -2.967 & 0.004 \\
\hline Overall stability index $\left[^{\circ}\right] /$ inflection point ICT [mm] & 142 & -0.00 & -0.017 & 0.986 \\
\hline Overall stability index $\left[^{\circ}\right] /$ kyphotic apex KA (VPDM) [mm] & 142 & 0.22 & 2.718 & 0.007 \\
\hline Overall stability index $\left[^{\circ}\right] /$ inflection point ITL [mm] & 142 & 0.08 & 0.909 & 0.365 \\
\hline Overall stability index $\left[^{\circ}\right] /$ lordotic apex LA [VPDM] [mm] & 142 & 0.12 & 1.264 & 0.209 \\
\hline Overall stability index $\left[^{\circ}\right] /$ inflection point ILS [mm] & 142 & 0.2 & 2.432 & 0.016 \\
\hline Overall stability index $\left[^{\circ}\right] /$ kyphotic angle ICT-ITL $[\max ]\left[^{\circ}\right]$ & 142 & 0.1 & 1.180 & 0.24 \\
\hline Overall stability index $\left[^{\circ}\right] /$ kyphotic angle VP-ITL $\left[^{\circ}\right]$ & 142 & 0.1 & 1.211 & 0.228 \\
\hline Overall stability index $\left[^{\circ}\right] /$ lordotic angle ICT-ITL $[\max ]\left[^{\circ}\right]$ & 142 & 0.1 & 1.211 & 0.228 \\
\hline Overall stability index $\left[^{\circ}\right] /$ lordotic angle ITL-DM $\left[^{\circ}\right]$ & 142 & 0.25 & 3.068 & 0.003 \\
\hline
\end{tabular}


Table 2. Correlations between stability index in the anterior-posterior plane (A/P) and body posture parameters in the group of studied girls

\begin{tabular}{|c|c|c|c|c|}
\hline Correlated parameters & $N$ & Spearman $R$ & $t(N-2)$ & $P$-value \\
\hline Anterior-posterior stability index $\left[^{\circ}\right] /$ trunk length VP-DM [mm] & 142 & -0.23 & -2.761 & 0.007 \\
\hline Anterior-posterior stability index $\left[^{\circ}\right] /$ trunk length VP-SP [mm] & 142 & -0.21 & -2.518 & 0.013 \\
\hline Anterior-posterior stability index $\left[^{\circ}\right] /$ trunk inclination VP-DM $\left[^{\circ}\right]$ & 142 & -0.2 & -2.383 & 0.018 \\
\hline Anterior-posterior stability index $\left[{ }^{\circ}\right] /$ trunk inclination VP-DM [mm] & 142 & -0.22 & -2.603 & 0.01 \\
\hline Anterior-posterior stability index $\left[{ }^{\circ}\right] /$ inflection point ICT [mm] & 142 & 0.03 & 0.327 & 0.744 \\
\hline Anterior-posterior stability index $\left[^{\circ}\right] /$ kyphotic apex KA [VPDM] [mm] & 142 & 0.19 & 2.235 & 0.027 \\
\hline Anterior-posterior stability index $\left[^{\circ}\right] /$ inflection point ITL [mm] & 142 & 0.06 & 0.671 & 0.503 \\
\hline Anterior-posterior stability index $\left[^{\circ}\right] /$ lordotic apex LA [VPDM] [mm] & 142 & 0.08 & 0.937 & 0.351 \\
\hline Anterior-posterior stability index $\left[^{\circ}\right] /$ inflection point ILS [mm] & 142 & 0.2 & 2.354 & 0.02 \\
\hline Anterior-posterior stability index $\left[^{\circ}\right] /$ kyphotic angle ICT-ITL $[\max ]\left[^{\circ}\right]$ & 142 & 0.08 & 0.987 & 0.326 \\
\hline Anterior-posterior stability index $\left[^{\circ}\right] /$ kyphotic angle VP-ITL $\left[^{\circ}\right]$ & 142 & 0.07 & 0.864 & 0.389 \\
\hline Anterior-posterior stability index $\left[^{\circ}\right] /$ lordotic angle ICT-ITL $[\max ]\left[^{\circ}\right]$ & 142 & 0.27 & 3.371 & 0.001 \\
\hline Anterior-posterior stability index $\left[^{\circ}\right] /$ lordotic angle ITL-DM $\left[^{\circ}\right]$ & 142 & 0.23 & 2.815 & 0.006 \\
\hline
\end{tabular}

Table 3. Correlations between stability index in the medial-lateral $(\mathrm{M} / \mathrm{L})$ plane and body posture parameters in the studied group of girls

\begin{tabular}{|c|c|c|c|c|}
\hline Correlated parameters & $N$ & Spearman $R$ & $t(N-2)$ & $P$-value \\
\hline Medial-lateral stability index $\left[^{\circ}\right] /$ trunk length VP-DM [mm] & 142 & -0.19 & -2.292 & 0.023 \\
\hline Medial-lateral stability index $\left[^{\circ}\right] /$ trunk length VP-SP [mm] & 142 & -0.2 & -2.360 & 0.02 \\
\hline Medial-lateral stability index $\left[^{\circ}\right] /$ trunk inclination VP-DM $\left[^{\circ}\right]$ & 142 & -0.21 & -2.496 & 0.014 \\
\hline Medial-lateral stability index $\left[^{\circ}\right] /$ trunk inclination VP-DM [mm] & 142 & -0.22 & -2.667 & 0.009 \\
\hline Medial-lateral stability index $\left[^{\circ}\right] /$ inflection point ICT [mm] & 142 & -0.03 & -0.355 & 0.723 \\
\hline Medial-lateral stability index $\left[^{\circ}\right] /$ kyphotic apex KA [VPDM] [mm] & 142 & 0.22 & 2.704 & 0.008 \\
\hline Medial-lateral stability index $\left[^{\circ}\right] /$ inflection point ITL [mm] & 142 & 0.11 & 1.273 & 0.205 \\
\hline Medial-lateral stability index $\left[^{\circ}\right] /$ lordotic apex LA [VPDM] [mm] & 142 & 0.12 & 1.484 & 0.14 \\
\hline Medial-lateral stability index $\left[^{\circ}\right] /$ inflection point ILS [mm] & 142 & 0.18 & 2.207 & 0.029 \\
\hline Medial-lateral stability index $\left[^{\circ}\right] /$ kyphotic angle ICT-ITL $[\max ]\left[^{\circ}\right]$ & 142 & 0.1 & 1.135 & 0.26 \\
\hline Medial-lateral stability index $\left[^{\circ}\right] /$ kyphotic angle VP-ITL $\left[^{\circ}\right]$ & 142 & 0.12 & 1.287 & 0.2 \\
\hline Medial-lateral stability index $\left[^{\circ}\right] /$ lordotic angle ICT-ITL $[\max ]\left[^{\circ}\right]$ & 142 & 0.26 & 3.123 & 0.002 \\
\hline Medial-lateral stability index $\left[^{\circ}\right] /$ lordotic angle ITL-DM $\left[^{\circ}\right]$ & 142 & 0.27 & 3.262 & 0.001 \\
\hline
\end{tabular}

VP-DM $(R=-0.24 ; p=0.004)$ (Table 1$)$. The stability Index in the anterior-posterior plane $(\mathrm{A} / \mathrm{P})$ obtained a higher value in the case of an increase in kyphosis peak value KA $(\mathrm{VPDM})(R=0.19 ; p=0.027)$, inflection point ILS $(R=0.2 ; p=0.02)$, lordosis angle ITL-ITS $(\max )(R=0.27 ; p=0.001)$, and lordosis angle ITS-DM $(R=0.23 ; p=0.006)$. Inversely proportional correlations were seen for trunk length VP-DM $(R=-0.23$; $p=0.007)$, trunk length VP-SP $(R=-0.21 ; p=0.013)$, trunk inclination VP-DM $(R=-0.2 ; p=0.018)$, and trunk inclination VP-DM $(R=-0.22 ; p=0.01)$ (Table 2$)$. Along with the increase in the stability index for the medial-lateral plane, there was also a rise in kyphosis peak value KA (VPDM) $(R=0.22 ; p=0.008)$, inflection point ILS $(R=0.18 ; p=0.029)$, lordosis angle ITL-ITS $(\max )(R=0.26 ; p=0.002)$, and lordosis angle ITS-DM $(R=0.27 ; p=0.001)$. However, a negative correlation occurred between the discussed parameter and trunk length VP-DM $(R=-0.19 ; p=0.023)$, trunk length VP-SP $(R=-0.2 ; p=0.02)$, trunk inclination VP-DM $(R=-0.21 ; p=0.014)$, and trunk inclination VP-DM $(R=-0.22 ; p=0.009)$ (Table 3).

\section{Discussion}

The development of incorrect posture and postural control itself is associated with abnormal sensory ex- 
periences, lack of proper postural tension or correct postural and motor patterns, as well as abnormal mutual innervation. It disrupts the central stabilisation of a child's body and its postural structure [19]. This was confirmed in the research by Bucci et al. [19], who analysed the role of proprioception in the balance of body posture among children with squint before and after alignment of visual axes. The results showed that after alignment of the visual axes, posture stability is enhanced, which suggests the main role of visual input in postural control compared to proprioceptive information. Similar conclusions were presented in the reports by Lions et al. [20], who compared the influence of proprioceptive information during postural control in children with squint and healthy children. The measurements were conducted with the Techno Concept platform using the Romberg and the Tandem tests. In both tests, the length, area, and average speed of the COP signal was significantly higher in children with visual impairment than in the control group. This means that children with squint are less stable than healthy children, and in postural control they predominantly use proprioceptive information. The results of research conducted by Gouleme et al. [21] on the importance of visual information in the postural control of dyslexic children indicate higher COP in children with the disorder, especially when assuming an eyesclosed position on an unstable surface, compared to the healthy population. This means that the impairment of cerebellar integration of all sensory inputs is responsible for postural deficits. Studies on the development of deaf children also indicate weaker stability control compared to healthy individuals. An example may be the results of research conducted by Ebrahimi et al. [22], the aim of which was to establish credibility and compare the static postural control of deaf children with that of normally developing peers. The study was conducted in two phases on 81 children aged 7-12 in Tehran schools. The Posturography Synapsys System (SPS) was used for measurements. During the first phase, the reliability of the static equilibrium assessment was examined, and then the static equilibrium of 30 children with sensorineural hearing loss (SNHL) was compared to a control group of 37 healthy children. The results showed that the limits of stability (LOS) and values of the children's overall stability index with typical development were better than those of deaf children. In addition, deaf children had lower static posture control in all sensory states.

Many researchers point to the desirability of using postural re-education exercises to improve balance through biofeedback on balance platforms. JankowiczSzymańska and Mikołajczyk [23] reported on the relationship between the body posture of school-age children and the use of exercises with balance platforms, confirming that regular exercises on an unstable surface improve body shape and prevent the occurrence of postural defects. Similar conclusions are presented by Maciaszek et al. [24], analysing the impact of sensory integration therapy among children aged 4-6 years, who were unable to maintain a stable position on one leg for $20 \mathrm{~s}$. The subjects were divided into two groups, one of which was a research group subjected to sensory integration therapy, and the other a control group. The results of the experiment showed that the ability to stand on one leg significantly improved $(p<0.01)$ in the group undergoing therapy. Similarly, changes were observed when standing with closed eyes. The conducted research shows a significant influence of sensory integration therapy (SIT) on children with low levels of postural stability.

In the literature on the subject, information on central nervous system dysfunctions is presented in connection with the discussion regarding normal and abnormal motor patterns [25-27]. A study by Wilczyński et al. evaluating posture and postural stability among Parkinson's disease patients showed significant relationships between body surface torsion and the overall stability index, and the anterior/ posterior stability index. The average square value of the surface on the line of symmetry showed a positive correlation with the overall stability index (SI) at the level of $p=0.0206, R=0.4075$ and body deflection in the anterior-posterior plane at the level of $p=0.310$, $R=0.3819$. The value of the right-sided surface rotation on the line of symmetry $(+\max )$ increased along with the increase in the overall stability index (SI) ( $p=0.0478, R=0.3526$ ) and the index of deflection in the anterior-posterior plane ( $p=0.0285, R=0.3873)$. The same authors analysed the relationship between parameters of body posture and postural stability among people training qigong [28].

Our research indicates a number of dependencies between body posture and postural stability parameters. Direct proportional correlations have shown that with the increase in posture stability, the values of postural variables also increased, which means that worse postural stability correlates with worse posture. Inverse proportional dependencies can be explained by the strategy of the hip joint, which causes the torso to tilt forward with the flexion of the hip joint.

It should be remembered that Spearman's correlation is one of the non-parametric measures of statistical dependence between random variables. It is not always a causal relationship. It does not indicate unambiguous connections between variables. Due to the very large number of factors, interactions between variables, and the cross-sectional nature of the empirical material, it is not possible to clearly indicate specific types of postures, which depend on the parameters of postural stability.

In addition, a large obstacle in comparing the results of this study with the outcomes of other authors is often related to the different methodology of con- 
ducted research, as well as the use of different measures, equations, and boundaries between postural defects and correct posture.

\section{Conclusions}

Demonstrating the links between parameters of body posture and postural stability indicates the need to include exercises in the field of central stabilisation regarding postural re-education programmes, which is the basis for obtaining a coordinated and ergonomic body system. For this purpose, exercises should be used to improve the proper posture habit in relation to the setting reactions and balance with the use biofeedback on the stabilometric and dynamographic platforms.

\section{Conflict of interest}

The authors declare no conflict of interest.

\section{References}

1. Wojna D, Anwajler J, Wujak A, Barczyk K. Assessment of body posture and physical fitness of younger school - age children. Med Sport 2013; 1: 27-36.

2. Bobath $K$. The normal postural reflex mechanism and its deviation in children with cerebral palsy. Physiotherapy 1971; 51: 515-525.

3. Velicković TD, Perat MV. Basic principles of neurodevelopmental treatment. Med 2005; 41: 112-120.

4. Nowotny J, Nowotny-Czupryna O, Czupryna K, Rottermund J. About scoliosis - another approach. Physiological and physiopathological basis of scoliosis therapy. Prz Med Uniw Rzesz Inst Leków 2012; 3: 341-350.

5. Gogola A, Matyja M, Kuszewski M. Commentary on development of low postural tone compensatory pattern predicted dysfunction patterns in lower part of the body. J Pediatr Neurol Med 2017; 2: 1.

6. Błaszczyk JW, Czerwosz L. Postural stability in the process of aging. Gerontol Pol 2005; 13: 25-36.

7. Rieman BL, Lephart SM. The sensorimotor system, part I: the physiologic basis of functional joint stability. J Athl Train 2002; 37: 71-79.

8. Wilczyński J. An outline of anatomy and physiology of the balance system. In: An Outline of Kinesiology. Kasperczyk T, Mucha D (eds.). Jet, Kraków 2016; 101-132.

9. Furian TC, Rapp W, Eckert S, Wild M, Betsch M. Spinal posture and pelvic position in three hundred forty-five elementary school children: a rasterstereographic pilot study. Orthop Rev (Pavia) 2013; 5: e7.

10. Humphries T, Baker M, Berakwell Lee T, Cole A, Hughes Lawson C, Naylor B, Michael A. Correlation of rotation parameters in scoliosis between radiographs and diers formetric scans. Bone Joint J 2014; 96-B no. Supp: 15-18.

11. Lason G, Peeters L, Vandenberghe K, Byttebier G, Comhaie F. Reassessing the accuracy and reproducibility of diers formetric measurements in healthy volunteers. Int J Osteopath Med 2015; 18: 247-254.

12. Hackenberg L, Hierholzer E, Pötzl W, Götze E, Liljenqvist U. Rasterstereographic back shape analysis in idiopathic scoliosis after posterior correction and fusion. Clin Biomech 2003; 18: 883-889.

13. Betsch M, Wild M, Jungbluth P, Thelen S, Hakimi M, Windolf J, Horstmann T, Rapp W. The rasterstereographic-dy- namic analysis of posture in adolescents using a modified Matthiass test. Eur Spine J 2010; 19: 1735-1739.

14. Betsch M, Wild M, Jungbluth P, Hakimi M, Windolf J, Haex B, Horstmann T, Rapp W. Reliability and validity of $4 \mathrm{D}$ rasterstereography under dynamic conditions. Comput Biol Med 2011; 41: 308-312.

15. User manual Diers formetric III 4D 2013.

16. User manual System Balansowy SD 2012.

17. Mangone M, Raimondi P, Paoloni M, Pellanera S, Di Michele A, Di Renzo S, Vanadia M, Dimaggio M, Murgia M, Santilli V. Vertebral rotation in adolescent idiopathic scoliosis calculated by radiograph and back surface analysis-based methods: correlation between the Raimondi method and rasterstereography. Eur Spine J 2013; 22: 367-371.

18. Wiszomirska I, Kaczmarczyk K, Zdrodowska A, Błażkiewicz M, Ilnicka L, Marciniak T. Evaluation of static and dynamic postural stability in young, elderly and with vision loss women. Post Rehab 2013; 3: 33-39.

19. Bucci MP, Soufi H, Villeneuve P, Colleville L, Bui-Quoc E, Lions C. Importance of proprioceptive information for postural control in children with strabismus before and after strabismus surgery. Front Syst Neurosci 2016; 10: 67.

20. Lions C, Colleville L, Bui-Qioc E, Bucci MP. Importance of visual inputs quality for postural stability in strabismic children. Neurosci Lett 2016; 617: 127-133.

21. Gouleme N, Vulleneuve P, Gerard CL, Bucci MP. Influence of both cutaneous input from the foot soles and visual information on the control of postural stability in dyslexic children. Gait Posture 2017; 56: 141-146.

22. Ebrahimi AA, Movallali G, Jamshidi AA, Rahgozar M, Haghgoo HA. Postural control in deaf children. Acta Med Iran 2017, 55: 115-122.

23. Jankowicz-Szymańska A, Mikołajczyk E. Use of unstable surfaces in preventing development of spinal deformities in children. Hygeia Public Health 2015; 50: 31-36.

24. Maciaszek J, Kilan J, Bronikowski M. Reaction to the sensory integration therapy in children with postural stability deficits. Minerva Pediatr 2016; 5.

25. Mitova S, Popova D, Gramatikova M. Postural disorders and spinal deformities in children at promary school age. System for screening, examination, prevention and treatment. Activ Phys Educ Sport 2014; 4: 172-177.

26. Maćków A, Małachowska-Sobieska M, Demczuk-Włodarczyk E, Sidorowska M, Szklarska A, Lipowicz A. Influence of neurophysiological hippotherapy on the transference of the centre of gravity among children with cerebral palsy. Ortop Traumatol Rehab 2014; 16: 581-593.

27. Wilczyński J, Pedrycz A, Mucha D, Ambroży T, Mucha D. Body posture and postural stability and metabolic age in patients with Parkinson's disease. BioMed Res Int 2017; 2017: 3975417.

28. Wilczyński J, Półrola P. Body posture and postural stability of people practicing qigong. Stud Med 2015; 31: 115-121.

\section{Address for correspondence:}

\section{Dr Katarzyna Bieniek}

Jan Kochanowski University Graduate in Physiotherapy Faculty of Health Sciences Jan Kochanowski University al. IX Wieków Kielc 19, Kielce, Poland

Phone: +48509044 796

E-mail: katarzyna.bieniek@onet.com.pl 